ISTIGHNA, Vol. 1, No 2, Juli 2018 P-ISSN 1979-2824

Homepage: http://e-journal.stit-islamic-village.ac.id/index.php/istighna

Amita Diananda

Urgensi Pendidikan Karakter Dalam Pembentukan Konsep Diri Anak

\title{
URGENSI PENDIDIKAN KARAKTER DALAM PEMBENTUKAN KONSEP DIRI ANAK
}

\author{
Amita Diananda \\ (amitadiananda@ rocketmail.com) \\ Dosen Sekolah Tinggi Ilmu Tarbiyah (STIT) Islamic Village Tangerang
}

\begin{abstract}
Abstrak: Pendidkan karakter yang ditanamkan sejak dini kepada anak bertujuan agar anak kelak sampai dewasa menjadi manusia yang bermartabat yaitu manusia yang mempunyai hati nurani, cerdas dalam bersikap dan bertuturkata. Tanggung jawab pendidikan karakter adalah orang yang terdekat dengan anak yaitu keluarga, sekolah dan masyarakat. Nilai-nilai karakter yang ditanamkan kepada anak meliputi : religius, jujur, toleransi, disiplin, kerja keras, kreatif, mandiri, demokrasi, rasa ingin tahu, semangat kebangsaan, cinta tanah air, menghargai prestasi, bersahabat, komunikatif, cinta damai, gemar membaca, peduli lingkungan, peduli sosial, dan bertanggung jawab. Pendidikan karakter pada setiap fase usia perkembangan anak berbeda-beda penanganannya, dari anak usia dini, anak-anak dan remaja, karena setiap fase mempunyai kebutuhan dan tantangan yang berbeda. Berkaitan dengan konsep diri anak, akan terbentuk dari perlakuan yang anak dapatkan terhadap dirinya baik itu dari lingkungan keluarga yang berkaitan pola asuh, budaya sekolah dan masyarakat. Penguatan pendidikan karakter dalam konteks sekarang sangat relevan untuk mengatasi krisis moral yang sedang terjadi di negara kita.
\end{abstract}

Kata Kunci : Karakter, Nilai Nilai Karakter, Konsep Diri.

\section{A. Pendahuluan}

Bangsa Indonesia saat ini diyakini sedang mengalami kerusakan moral atau akhlak hampir pada semua segmen kehidupan dan seluruh lapisan masyarakat. Banyak bukti yang menjelaskan terjadinya kerusakan moral masyarakat tersebut. Pada tingkat elit (pemimpin), rusaknya moral bangsa ini ditandai dengan maraknya prkatek Korupsi, Kolusi, dan Nepotisme (KKN) pada semua instansi pemerintah dari tingkat paling atas sampai tingkat bawah. Berdasarkan Indeks prestasi Korupsi (IPK), praktik KKN di Indonesia tahun 2010 naik menjadi 2,8 dari 2,6 pada tahun 2009. Dengan skor ini Indonesia termasuk negara yang paling korup pertama dari 12 negara di Asia dan berada urutan ke tiga dari 180 negara di dunia berdasarkan hasil penilaian lembaga penelitian internasional, seperti Political and Economic Rich Consultancy di Hongkong dan Transparancy Global Index di Jerman. ${ }^{1}$

\footnotetext{
${ }^{1}$ Amrullah Syahrbini, Model Pendidikan Karakter Dalam Keluarga, (Jakarta: PT Elex Media Komputindo, 2014), h. V.
} 
ISTIGHNA, Vol. 1, No 2, Juli 2018 P-ISSN 1979-2824

Homepage: http://e-journal.stit-islamic-village.ac.id/index.php/istighna

Amita Diananda Urgensi Pendidikan Karakter Dalam Pembentukan Konsep Diri Anak

Sedangkan dikalangan anak-anak muda krisis moral juga banyak terjadi misalnya dalam pergaulan seks bebas sehingga sampai ada istilah "Kumpul Kebo". Kumpul Kebo berasal dari istilah zaman dulu, yaitu 'Koempoel Gebouw'. Dalam bahasa Belanda, gebouw bermakna bangunan atau rumah. Jadi, koempoel gebouw maksudnya adalah berkumpul di bawah satu atap rumah (tanpa ikatan pernikahan). Atau praktek seks bebas di luar pernikahan. ${ }^{2}$

Kekerasan dalam bentuk premanisme juga marak dikalangan remaja. Seperti premanisme yang dilakukan oleh pelajar yang tergabung dalam Geng Nero (Neko-neko dikeroyok), dan banyak lagi kekerasan yang lainnya. Geng nero barangkali hanya salah satu potret dari sekian banyak geng yang ada di lingkungan masyarakat yang dilakukan oleh pelajar. ${ }^{3}$ Pergaulan bebas dan kekerasan yang terjadi diperkuat oleh penelitian BKKBN. ${ }^{4}$

Menurut Kepala BKKBN, Sugiri Syarif, data badan Koordinasi Berencana Nasional (BKKBN) pada tahun 2010, menunjukkan 51 persen remaja di Jabodetabek telah melakukan seks pranikah. Artinya dari 100 remaja, 51 sudah tidak perawan. Beberapa wilayah lain Indonesia, seks pranikah juga dilakukan beberapa remaja. Misalnya saja di Surabaya tercatat 54 persen, di Bandung 47 persen, dan 52 persen di Medan. Dari kasus perzinaan yang dilakukan para remaja putri tersebut, yang pailng dahsyat terjadi di Yogyakarta. Pihaknya mnyebutkan dari hasil penelitian di Yogyakarta kurun waktu 2010 setidaknya tercatat sebanyak 37 persen dari 1.160 mahasiswi di Kota Gudeg ini menerima gelar MBA (marriage by accident) alias menikah akibat hamil maupun kehamilan. Di luar nikah. Didit Tri Kertapi Kepala BKKBN mengungkapkan 51 remaja dari 100 remaja di

\footnotetext{
${ }^{2}$ https://www.kompasiana.com/iskandarjet/5a39dd26f13344645732dea2/inilah-asal-usulistilah-kumpul-kebo

${ }^{3}$ Dimyati, Peran Guru sebagai Model dalam Pembelajaran Karakter dan Kebajikan Moral melalui Pendidikan Jasmani, (Yogyakarta: UNY, 2010, Th.XXIX)Ed. Khusus Dies Natalis UNY). h. 84 .

${ }^{4}$ Zubaidi, Desain Pendidikan Karakter Konsepsi dan Aplikasinya dalam Lembaga Pendidikan, (Jakarta: Penerbit Kencana, 2011), Ed. 1. h.1.
} 
ISTIGHNA, Vol. 1, No 2, Juli 2018 P-ISSN 1979-2824

Homepage: http://e-journal.stit-islamic-village.ac.id/index.php/istighna

Amita Diananda Urgensi Pendidikan Karakter Dalam Pembentukan Konsep Diri Anak

Jabodetabek sudah tak perawan ${ }^{5}$. (Dalam detiknews.com, dipublikasikan pada tanggal 28/11/2010).

Pendidikan adalah salah satu usaha untuk mengatasi masalah-masalah tersebut diatas. Baik melalui pendidikan formal yaitu di sekolah, juga pendidikan informal yaitu kelurga yang diperkuat dengan pendidikan karakter. Dalam konteks pendidikan formal di sekolah, bisa jadi salah satu penyebabnya karena di Indonesia lebih menitikberatkan pada pengembangan inlektual atau kognitif semata, sedangkan aspek soft skills, atau non akademik sebagai unsur utama pendidikan karakter belum diperhatikan secara optimal bahkan cenderung diabaikan. Saat ini, ada kecenderungan bahwa target-target akademik masih menjadi tujuan dari hasil pendidikan, seperti halnya Ujian Nasional (UN), sehingga proses pendidikan karakter masih sulit dilakukan. ${ }^{6}$ Sedangkan pendidikan informal yaitu keluarga disebabkan karena berbagai sebab misalnya, beragam pola asuh orangtua, kurang perhatian, pendidikan orangtua, ekonomi keluarga, faktor budaya setempat, traumatik dan lain sebagainya.

Diakui, persoalan karakter atau moral memang tidak sepenuhnya kesalahan oleh lembaga pendidikan. Akan tetapi, fakta-fakta kemorosotan karakter pada sekitar kita dalam hal menumbuhkan manusia yang berkarakter dan berakhlak mulia masih perlu diperkuat lagi.

Di Indonesia praktik pendidikan karakter sebenarnya berlangsung sudah lama, jauh sebelum Indonesia merdeka, seperti praktik pendidikan yang dilakukan oleh Ki Hajar Dewantara, R.A Kartini, M Natsir, Hasyim Asyari, Ahmad Dahlan, dan tokoh-tokoh lainnya. Hanya pada saat itu belum ada istilah pendidikan karakter. Istilah itu mulai populer sekitar tahun 2000-an dan dipelopori oleh Ir. Rartna Megawangi, M.Sc. ${ }^{7}$

\section{B. Definisi Pendidikan Karakter}

Secara etimologis, kata karakter berasal dari bahasa Latin kharakter atau bahasa Yunani kharassein yang berarti memberi tanda (to mark), atau bahasa

\footnotetext{
${ }^{5}$ http://www.detiknews.com/read/2010/11/28/094930/1504117/10/kepala-bkkbn-51-dari 100 remaja di jabodetabek.sudah - tak-perawan.

${ }^{6}$ Ibid., h. 3

${ }^{7}$ Amrullah Syahrbini, Model Pendidikan Karakter Dalam Keluarga., op.cit., h. 12.
} 
ISTIGHNA, Vol. 1, No 2, Juli 2018 P-ISSN 1979-2824

Homepage: http://e-journal.stit-islamic-village.ac.id/index.php/istighna

Amita Diananda Urgensi Pendidikan Karakter Dalam Pembentukan Konsep Diri Anak

Prancis caracter, yang berarti membuat tajam atau membuat dalam (Majid dan Andayani, 2012:11). Dalam bahasa Ingris character, memiliki arti watak, karakter, sifat, peran dan huruf (Echols dan Shadili, 2003 : 110) Karakter juga diberi arti a distinctive differinting mark (tanda atau sifat yang membedakan seseorang dengan orang lain). ${ }^{8}$ Sedangkan secara terminologis, kata karakter menurut Endang Sumantri adalah suatu kualitas positif yang dimiliki seseorang, sehingga membuatnya menarik dan atraktif, seseorang yang unusual atau memiliki kepribadian ekssentrik. Menurut Doni Koesuma karakter sama dengan kepribadian. ${ }^{9}$

Karakter menurut Kamus Besar Bahasa Indonesia (KBBI) karakter $n$ 1. tabiat, sifat-sifat kejiwaan, akhlak atau budi pekerti yang membedakan seseorang dengan yang lain, watak. 2. huruf, angka, ruang, simbol khusus yang dapat dimunculkan pada layar dengan papan ketik berkarakter mempunyai tabiat, mempunyai kepribadian, berwatak: anak itu $\sim$ aneh. ${ }^{10}$

Berdasarkan penjelasan para ahli diatas dapat ditarik benang merah, karakter adalah sifat yang mantap, stabil, dan khusus yang melekat dalam diri seseorang yang membuatnya bersikap dan bertindak otomatis, tidak dapat dipengaruhi oleh keadaan, dan tanpa memerlukan pemikiran atau pertimbangan terlebih dahulu. Pengertian karakter seperti ini sama dengan definisi akhlak dalam Islam yaitu, perbuatan yang telah menyatu dalam jiwa atau diri seseorang atau spontanitas dan bersikap sehingga ketika muncul tidak perlu dipikirkan lagi. ${ }^{11}$

Sedangkan pendidikan karakter menurut Thomas Lichona adalah upaya membentuk atau mengukir kepribadian manusia melalui proses knowing the good (mengetahui kebaikan), loving the good (mencintai kebaikan), acting the good (melakukan kebaikan), yaitu proses pendidikan yang melibatkan tiga ranah: pengetahuan moral (moral knowing), perasaan moral (moral feeling atau moral loving), dan tindakana moral (moral actingatau moral doing), sehingga perbuatan

\footnotetext{
${ }^{8}$ Amrullah Syahrbini, Model Pendidikan Karakter Dalam Keluarga., op.cit.,h.9.

${ }^{9}$ Ibid.

${ }^{10}$ https://kbbi.web.id/karakter Sumber: Kamus Bahasa Indonesia edisi elektronik (2008).

${ }^{11}$ Ibid., h. 10.
} 
ISTIGHNA, Vol. 1, No 2, Juli 2018 P-ISSN 1979-2824

Homepage: http://e-journal.stit-islamic-village.ac.id/index.php/istighna

Amita Diananda Urgensi Pendidikan Karakter Dalam Pembentukan Konsep Diri Anak

mulia bisa terukir menjadi habit of mind, heart, and hands. Tanpa melibatkan ketiga ranah tersebut pendidikan karakter tidak akan berjalan efektif. ${ }^{12}$

Sehingga dapat dikatakan bahwa pendidikan karakter merupakan sebuah proses untuk menumbuhkan, mengembangkan, mendewasakan, manata, mengarahkan agar potensi yang ada pada diri anak bisa muncul serta berkepribadian baik yang nantinya dapat bermanfaat bagi dirinya dan juga lingkungannya.

Jika mengacu pada Pedoman Pendidikan Karakter yang di keluarkan oleh Kemendiknas, materi karakter di lembaga formal (sekolah), setidaknya memuat 18 (delapan belas) nilai karakter, yaitu : (1) religius, (2) jujur, (3) toleransi, (4) didiplin, (5) kerja keras, (6) kreatif, (7) mandiri, (8) demokratis, (9) rasa ingin tahu, (10) semangat kebangsaan, (11) cinta tanah air, (12) menghargai prestasi, (13) bersahabat/ komunikatif, (14) cinta damai, (15) gemar membaca, (16) peduli lingkungan, (17) peduli sosial, dan (18) tanggung jawab. ${ }^{13}$

Pendidikan karakter yang ditanamkan pada anak akan membentuk konsep diri anak. Konsep diri anak akan terus mengalami perubahan dari masa kecil sampai dewasa. Konsep diri anak akan bertambah baik dan matang tergantung pada pengalaman pribadinya selama berinteraksi dengan lingkungannya. Karena itu apabila pendidikan karakter sudah tertanam sejak kecil maka diharapkan kelak anak menjadi pribadi yang mulia terhindar dari tindakan-tindakan dan sikap yang melanggar hukum. Konsep diri anak akan semakin matang.

\section{Jenis-Jenis Pendidikan Karakter}

Ada empat jenis karakter yang selama ini dikenal dan dilaksanakan dalam proses pendidikan, yaitu sebagai berikut: ${ }^{14}$

1. Pendidikan karakter berbasis nilai religius, yang merupakan kebenaran wahyu Tuhan (konversi moral).

\footnotetext{
${ }^{12}$ Amrullah Syahrbini, Model Pendidikan Karakter Dalam Keluarga., op.cit.,h. 13.

${ }^{13}$ Ibid., h. 57

${ }^{14}$ Yahya Khan, Pendidikan Karakter Berbasis Potensi Diri, (Yogyakarta: Pelangi Publishing, 2010), Cet.1.h. 2.
} 
ISTIGHNA, Vol. 1, No 2, Juli 2018 P-ISSN 1979-2824

Homepage: http://e-journal.stit-islamic-village.ac.id/index.php/istighna

Amita Diananda Urgensi Pendidikan Karakter Dalam Pembentukan Konsep Diri Anak

2. Pendidikan karakter berbasis nilai budaya, antara lain yang berupa budi pekerti, pancasila, apresiasi sastra, keteladanan, tokoh -tokoh sejarah, dan para pemimpin bangsa (konservasi lingkungan).

3. Pendidikan karakter berbasis lingkungan (konservasi lingkungan).

4. Pendidikan karakter berbasis potensi diri, yaitu sikap pribadi, hasil proses kesadaran pemberdayaan potensi diri yang diarahkan untuk meningkatkan kualitas pendidikan (konservasi humanis).

Dari empat jenis pendidikan karakter dapat diuraikan sebagai berikut:

1. Pendidikan Karakter Berbasis Nilai Religius

a. Pada Usia Anak -Anak

Manusia dilahirkan dalam keadaan lemah fisik maupun psikis. Walaupun dalam keadaan yang demikian, ia telah memiliki kemampuan bawaan yang bersifat "laten". Potensi bawaan ini memerlukan pengembangan melalui bimbingan dan pemeliharaan yang mantap, lebihlebih pada usia dini termasuk dalam fitrah atau potensi keagamaan atau bersifat spiritual.

Ada beberapa teori mengenai pertumbuhan agama pada anak antara lain: ${ }^{15}$

(1). Rasa ketergantungan (Sense of Dependent)

Teori ini dikemukakan oleh Thomas melalui teori Four Wishes. Menurutnya, manusia dilahirkan ke dunia ini memiliki empat keinginan yaitu: keinginan untuk perlindungan (security), keinginan akan pengalaman baru (exexperience), keinginan untuk mendapat tanggapan (response), dan keinginan untuk di kenal (recognation). Berdasarkan kenyataan dan kerja sama dari keempat keinginan itu, maka sejak bayi dilahirkan hidup dalam ketergantungan, melalui pengalaman-pengalaman yang diterimanya dari lingkungan itu kemudian terbentuklah rasa keagamaan.

${ }^{15}$ Jalaluddin, Psikologi Agama, (Jakarta: PT Raja Grafindo Persada, 2004), Ed. Revisi .Cet.8.h. 65-66. 
ISTIGHNA, Vol. 1, No 2, Juli 2018 P-ISSN 1979-2824

Homepage: http://e-journal.stit-islamic-village.ac.id/index.php/istighna

Amita Diananda Urgensi Pendidikan Karakter Dalam Pembentukan Konsep Diri Anak

(2). Instink Keagamaan

Menurut Woodwort, bayi yang dilahirkan sudah memiliki beberapa insting diantaranya keagamaan. Belum terlihatnya tindak keagaman pada diri anak karena beberapa fungsi kejiwaan yang menopang kematangan berfungsinya insting itu belum sempurna. Misalnya, insting sosial pada anak sebagai potensi bawaannya sebagai makhluk homo socius, baru akan berfungsi setelah anak dapat bergaul dan berkemampuan untuk berkomunikasi. Jadi insting sosial itu tergantung dari kematangan fungsi lainnya. Demikian juga insting keagamaan.

Melihat dari teori Thomas melalui teori Four Wishes menyatakan bahwa pertumbuhan agama pada anak diawali dari rasa ketergantungan anak kepada orang dewasa dan menurut Woodwoort dari potensi bawaan insting. Menurut penulis fase ini bermakna secara psikologi anak harus terus ditumbuhkan dan dikembangkan oleh orang yang paling dekat dengannya yaitu pengasuhnya atau orangtuannya. Merekalah orang yang sering berinteraksi secara langsung sehingga perilaku keagamaan bisa diserap oleh anak. Misalnya perilaku orang tua memberi contoh sering pergi ketempat ibadah, merayakan hari-hari besar agama, mengawali sesuatu pekerjaan dengan menyebut nama Tuhan dan ucapan ucapan baik yang dicontohkan. Walupun anak-anak belum menyadari sepenuhnya manfaat ajaran agama.

Agar lebih terserap dalam menanamkan pendidikan karakter religius pada usia anak-anak sampai remaja sehingga terlihat dalam pribadi objek sasaran, yaitu pribadi yang berkarakter, maka perlu mengetahui tahapan atau fase yang dibutuhkan di usia itu. Perkembangan agama pada anak menurut penelitian Ernest Harms, melalui beberapa fase (tingkatan). Dalam bukunya The Development os 
ISTIGHNA, Vol. 1, No 2, Juli 2018 P-ISSN 1979-2824

Homepage: http://e-journal.stit-islamic-village.ac.id/index.php/istighna

Amita Diananda Urgensi Pendidikan Karakter Dalam Pembentukan Konsep Diri Anak

Religius on Children, menyatakan bahwa perkembangan agama pada anak-anak itu melalui tiga tingkatan, yaitu: ${ }^{16}$

(1). The Fairy Tale Stage (Tingkat Dongeng)

Tingkatan ini dimulai pada anak yang berusia 3-6 tahun. Pada tingkatan ini konsep mengenai Tuhan lebih banyak dipengaruhi oleh fantasi dan emosi. Pada tingkat perkembangan ini anak menghayati konsep ke-Tuhanan sesuai dengan tingkat perkembangan intelektualnya. Kehidupan masa ini masih banyak dipengaruhi kehidupan fantasi, sehingga dalam menanggapi agama pun anak masih menggunakan konsep fantasi yang diliputi oleh dongeng-dongeng yang kurang masuk akal.

(2). The Realistic Stage (Tingkat Kenyataan)

Tingkat ini dimulai sejak anak masuk Sekolah Dasar hingga ke usia (masa usia) remaja (adolesense). Pada masa ini, ide keTuhanan anak sudah mencerminkan konsep-konsep yang berdasarkan kepada kenyataan (realistik) dan atas dorongan anak didasarkan atas dorongan emosional, hingga mereka dapat melahirkan konsep Tuhan yang formalis.

(3). The Individual Stage (Tingkat Individu)

Pada tingkat ini anak telah memiliki kepekaan emosi yang paling tinggi sejalan dengan perkembangan usia mereka. Konsep keagamaan yang individualistis ini terbagi atas tiga golongan, yaitu: Pertama, Konsep ke-Tetuhanan yang konvensional dan konservatif dengan dipengaruhi sebagaian kecil fantasi. Hal ini tersebut disebabkan oleh pengaruh luar. Kedua, Konsep ke-Tuhanan yang lebih murni yang dinyatakan dalam pandangan yang bersifat personal (perorangan). Ketiga, Konsep ke-Tuhanan yang bersifat humanistik, agama telah menjadi etos humanis pada diri mereka dalam menghayati

\footnotetext{
${ }^{16}$ Ibid., h. 66-67
} 
ISTIGHNA, Vol. 1, No 2, Juli 2018 P-ISSN 1979-2824

Homepage: http://e-journal.stit-islamic-village.ac.id/index.php/istighna

Amita Diananda Urgensi Pendidikan Karakter Dalam Pembentukan Konsep Diri Anak

ajaran agama. Perubahan ini setiap tingkatan dipengaruhi oleh faktor intern, yaitu perkembangan usia dan faktor ekstern berupa pengaruh luar.

Memahami konsep keagamaan pada anak-anak berarti memahami sifat agama pada anak-anak. Perlu dijelaskan sifat agama pada anak-anak adalah $:^{17}$

(1). Unreflective (tidak Mendalam)

Dalam penelitian Machion tentang sejumlah konsep keTuhanan pada diri anak $73 \%$ merek menganggap Tuhan itu bersifat seperti manusia. Dengan demikian, anggapan mereka terhadap ajaran agama dapat saja mereka terima dengan tanpa kritik. Meskipun demikian, pada beberapa anak memiliki ketajaman pikiran untuk menimbang pendapat yang mereka terima dari orang lain. Penelitian Puff mengemukakan satu contoh tentang hal tersebut misalnya seorang anak perempun diberitahukan tentang doa yang dapat mengerakkan sebuah gunung. Berdasarkan pengetahuan tersebut maka pada suatu kesempatan anak itu berdoa selama beberapa jam agar Tuhan memindahkan gunung-gunung yang ada di derah Washington ke laut. Karena keinginan itu tidak terwujud, maka semenjak itu ia tidak mau berdoa lagi. Dari contoh ini menunjukkan bahwa anak sudah menunjukkan pemikiran kritis, walaupun bersifat sederhana. Pikiran kritis anak baru muncul pada usia 12 tahun sejalan dengan pertumbuhan moral. Disini mejelaskan bahwa anak meragukan kebenaran ajaran agama pada aspek-aspek yang bersifat konkret.

(2). Egosentris

Konsep keagamaan pada anak, mereka pandang dari kesenangan pribadinya.

(3). Antromorphis

\footnotetext{
${ }^{17}$ Ibid., h. 70-74.
} 
Pada umumnya konsep mengenai ke-Tuhanan pada anak- anak berasal dari hasil pengalamannya dikala ia berhubungan dengan orang lain. Melalui konsep yang terbentuk dalam pikiran, mereka menganggap Tuhan itu sama dengan manusia Misalnya Tuhan mempunyai wajah seperti manusia, telinganya lebar dan besar, Tuhan tidak makan tetapi hanya minum embun dan lain sebagainya.

(4). Verbalis dan Ritualis

Kehidupan agama pada anak-anak sebagian besar tumbuh mula-mula secara vebal (ucapan). Latihan-latihan yang bersifat verbalis dan upacara keagamaan yang bersifat ritualis (praktik) merupakan hal yang berarti dan merupakan salah satu ciri dari tingkat perkembangan agama pada anak-anak.

(5). Imitatif dan rasa heran

Sifat beragama pada anak adalah suka meniru atau peniru ulung. Dan ini merupakan modal yang positif dalam pendidikan agama pada anak. Walaupun anak mendapatkan ajaran agama tidak semata mata berdasarkan yang mereka peroleh sejak kecil, namun pendidikan keagamaan sangat mempengaruhi terwujudnya tingkah laku keagamaan melalui sifat meniru

(6). Rasa heran

Rasa heran dan kagum merupakan tanda dan sifat keagamaan yang terakhir pada anak. Berbeda rasa kagum pada orang dewasa, maka rasa kagum ini belum bersifat kritis dan kreatif. Mereka hanya kagum pada sesuatu yang bersifat lahiriyah saja. Rasa kagum pada mereka dapat disalurkan melalui cerita-cerita yang menimbulkan rasa takjub.

Pada pendidikan karakter anak usia dini berbeda dengan anak usia setelahnya, pada anaka usia dini (usia nol tahun sampai enam tahun) yaitu seperti yang telah dituangkan dalam UU Sisdiknas No. 20/2003 
ISTIGHNA, Vol. 1, No 2, Juli 2018 P-ISSN 1979-2824

Homepage: http://e-journal.stit-islamic-village.ac.id/index.php/istighna

Amita Diananda Urgensi Pendidikan Karakter Dalam Pembentukan Konsep Diri Anak

pasal 1 angka 14: Pendidikan anak usia dini adalah suatu upaya pembinaan yang ditujukan kepada anak sejak lahir sampai dengan usia enam tahun yang dilakukan melalui pemberian rangsangan pendidikan untuk membantu pertumbuhan dan perkembangan jasmani dan rohani agar anak memiliki kesiapan dalam memasuki pendidikan lebih lanjut. ${ }^{18}$ memang belum saatnya harus beradap atau beretika dalam arti tertib dan disiplin. Adab usia dini adalah gairah untuk melakukan kebaikan, bukan sempurna melakukan kebaikan. Banyak orangtua atau guru, ingin anakanaknya segera beradap sejak dini, tanpa tahu makna adab, walhasil kelak menjumpai anaknya malah tidak beradap ketika besar. Misalnya adab pada usia dini berbeda dengan adab pada usia setelahnya. Di usia dini, adab pada ilmu bukanlah duduk diam tertib santun mendengarkan guru, tetapi adalah gairah dan cinta pada buku, gairah pada kisah-kisah tokoh ilmuwan, gairah keseruan bermain dialam terbuka dengan menyentuh, meraba, berlarian bereksploreasi dan seterusnya.

Jadi bagi orangtua, turunkan ekspektasi, jangan artikan adab sebagai disiplin formal dan etika untuk usia dini, jangan tergesa-gesa mengadabkan sehingga harus sempurna dan tertib, jangan gunakan ukuran orang dewasa, nanti anak akan malah membenci adab sepanjang hidupnya.

b. Pada Usia Remaja

Perkembangan pemahaman remaja yaitu diusia 10 -21 tahun, terhadap keyakinan agama ini sangat dipengaruhi oleh perkembangan kognitifnya. Oleh karena itu meskipun pada masa awal anak-anak ia telah diajarkan agama oleh orang tua mereka, namun karena pada masa remaja mereka mengalami kemajuan dalam perkembangan kognitif, mereka mungkin mempertanyakan tentang kebenaran keyakinan agama mereka sendiri. Sehubungan dengan pengaruh perekembangan kognitif terhadap perkembangan agama selama masa remaja ini.

\footnotetext{
${ }^{18} \mathrm{http}: / /$ nopawilyanita.blogspot.com/2014/02/pendidikan-anak-usia-dini-paud-dan.html
} 
ISTIGHNA, Vol. 1, No 2, Juli 2018 P-ISSN 1979-2824

Homepage: http://e-journal.stit-islamic-village.ac.id/index.php/istighna

Amita Diananda Urgensi Pendidikan Karakter Dalam Pembentukan Konsep Diri Anak

Perkembangan agama pada remaja ditandai oleh beberapa faktor perkembangan rohani dan jasmani. Perkembangan itu antara lain menurut W. Starbuck adalah ${ }^{19}$ sifat kritis terhadap ajaran agama mulai timbul. Selain masalah agama mereka pun sudah tertarik pada masalah kebudayaan, sosial, ekonomi, dan norma norma kehidupan lainnya. Ajaran agama yang sifatnya konservatif lebih banyak berpengaruh bagi remaja untuk tetap taat pada ajaran agamanya. Sebaliknya, ajaran agama yang ajarannya kurang konservatif-dogmatis dan agak liberal akan mudah merangsang pengembangan pikiran dan mental para remaja, sehingga mereka banyak meninggalkan ajaran agamanya. Hal ini menunjukkan bahwa perkembangan pikiran dan mental remaja mempengaruhi keagamaan mereka

\section{Pendidikan Karakter Berbasis Nilai Budaya}

Budaya atau kebudayaan berasal dari bahasa Sanskerta yaitu buddhayah, yang merupakan bentuk jamak dari buddhi (budi atau akal) diartikan sebagai hal-hal yang berkaitan dengan budi, dan akal manusia. Dalam bahasa Inggris, kebudayaan disebut culture, yang berasal dari kata Latin Colere, yaitu mengolah atau mengerjakan. Bisa diartikan juga sebagai mengolah tanah atau bertani. Kata culture juga kadang diterjemahkan sebagai "kultur" dalam bahasa Indonesia. ${ }^{20}$

Konsep pendidikan berbasis budaya adalah pendidikan yang diselenggarakan untuk memenuhi standar nasional pendidikan yang diperkaya dengan keunggulan komparatif dan kompetitif berdasar nilai-nilai luhur budaya agar peserta didik secara aktif dapat mengembangkan potensi diri sehingga menjadi manusia yang unggul, cerdas, visioner, peka terhadap lingkungan dan keberagaman budaya, serta tanggap terhadap perkembangan dunia. $^{21}$

\footnotetext{
${ }^{19}$ Ibid., 74-75.

${ }^{20}$ https://id.wikipedia.org/wiki/Budaya

${ }^{21}$ https://www.kompasiana.com/m.trimanto/5893efcbf692733a1bf67257/pendidikanberbasis-budaya
} 
ISTIGHNA, Vol. 1, No 2, Juli 2018 P-ISSN 1979-2824

Homepage: http://e-journal.stit-islamic-village.ac.id/index.php/istighna

Amita Diananda Urgensi Pendidikan Karakter Dalam Pembentukan Konsep Diri Anak

Konsep budaya yang diterapkan di keluarga bukan merupakan hal yang mudah, namun bisa diupayakan dengan strategi keteladanan, pembiasaan dan tindakan nyata. Nilai- nilai karakter tersebut bisa bersumber dari ajaran agama, falsafah dan budaya bangsa, atau normanorma dan nilai-nilai kearifan lokal (local wisdom) yang berlaku di masyarakat. Contoh sederhana nilai nilai budaya adalah menggunakan bahasa daerah masing-masing didalam keluarga (bahasa jawa, sunda, batak dan lain lain). Mencintai produk-produk buatan lokal, melestraikan adat istiadat dari leluhur.

3. Pendidikan Karakter Berbasis Lingkungan (Konservasi Lingkungan).

Manusia dan lingkungan memiliki hubungan yang tidak dapat terpisahkan. Manusia sangat bergantung pada lingkungan yang memberikan sumberdaya alam untuk tetap bertahan hidup. Adanya keterbatasan daya dukung (carrying capacity) lingkungan, menyebabkan manusia harus memperhatikan kelestarian lingkungan agar fungsi-fungsi lingkungan dapat berjalan sehingga dapat mendukung penghidupan berkelanjutan. Untuk membentuk manusia yang sadar akan pentingnya lingkungan bagi kehidupan maka perlu usaha yang dapat membina, mengarahkan dan menjadikan seseorang mempunyai jiwa mencintai lingkungan hidup.

Sekolah sebagai lembaga pendidikan formal merupakan wadah yang tepat untuk membentuk karakter membangun lingkungan. Sekolah memberikan pengalaman belajar, memberikan motivasi yang positif bagaimana menjaga keberlangsungan lingkungan sekolah supaya tetap asri, sejuk dan sehat. Begitupun di rumah juga ditanamkan menjaga dan mencintai lingkungan dengan cara bertanam dan merawat tanaman, membuang sampah pada tempatnya dan banyak aksi-aksi yang lain.

Tujuan pendidikan karakter peduli lingkungan adalah: 1) Mendorong kebiasaan dan perilaku anak yang terpuji dan sejalan dengan pengelolaan lingkungan yang benar; 2) Meningkatkan kemampuan untuk menghindari sifat-sifat yang dapat merusak lingkungan; 3) Memupuk kepekaan peserta didik terhadap kondisi lingkungan sehingga dapat menghindari sifat-sifat 
ISTIGHNA, Vol. 1, No 2, Juli 2018 P-ISSN 1979-2824

Homepage: http://e-journal.stit-islamic-village.ac.id/index.php/istighna

Amita Diananda Urgensi Pendidikan Karakter Dalam Pembentukan Konsep Diri Anak

yang dapat merusak lingkungan; 4) Menanam jiwa peduli dan bertanggung jawab terhadap kelestarian lingkungan. ${ }^{22}$

\section{Pendidikan Karakter Berbasis Potensi Diri}

Pendidikan karakter berbasis potensi diri merupakan proses kegiatan yang mengarah pada kualitas pendidikan dan pengembangan budaya harmoni yang selalu mengajarkan, membimbing, dan membina setiap manusia untuk memiliki kompetensi intelektual, (Kognitif), karakter ( Affective), dan kompetensi ketrampilan mekanik (Pschomotoric).

Pengolahan ke empat potensi tersebut juga merupakan desain induk dari pendidikan karakter yang memiliki tujuan menjadikan manusia yang bisa memaksimalkan segala potensi yang dimilikinya. Adapun tujuan pengolahan keempat potensi manusia tersebut adalah : ${ }^{23}$

a. Karakter yang bersumber dari olah hati, antara lain : beriman dan bertaqwa, bersyukur, jujur, amanah, tertib, sabar, disiplin, taat aturan, bertanggung jawab, berempati, punya rasa iba, berani mengambil resiko, pantang menyerah dll.

b. Karakter yang bersumber dari olah fikir, antara lain: cerdas, kritis, kreatif, inovatif, analitis ingin tahu, produktif, berorientasi pada iptek, dan reflektif

c. Karakter dari olah raga atau kinestetika, antara lain: bersih, dan sehat, sportif, tangguh, andal, berdaya tahan, berahabat, koopratif, ceria, ulet dan gigih.

d. Karakter dari olah rasa dan karsa, antara lain: kemanusian, saling menghargai, saling mengasihi, gotong royong, saling kebersamaan, ramah, peduli, toleran, nasionlis, kosmopolit (mendunia), mengutamakan kepentingan umum, dinamis, kerja keras dan beretos kerja.

\footnotetext{
${ }^{22} \mathrm{http} / / / \mathrm{www}$. rakyatpos.com/membangun-karakter-peduli-lingkungan-di-sekolah-upayapenyelematan-lingkungan-hidup.html/

${ }^{23}$ Kak Hendri, Pendidikan Karakter Berbasis Dongeng,(Bandung, Simbiosa Rekatama Media), Cet.1.h. 3 -4
} 
ISTIGHNA, Vol. 1, No 2, Juli 2018 P-ISSN 1979-2824

Homepage: http://e-journal.stit-islamic-village.ac.id/index.php/istighna

Amita Diananda Urgensi Pendidikan Karakter Dalam Pembentukan Konsep Diri Anak

Setiap anak itu unik mereka masing-masing memilki potensi terpendam. Dalam pendidikan karakter semua potensi yang dimiliki anak harus digali, diberdayakan untuk bekal hidup mereka. Potensi diri meliputi etos belajar, idealisme pendidikan, mind mapping ( penataan informasi agar mudah diakses), multiple intelegensi (kecerdasan ganda), public speaking (ketrampilan berbicara didepan umum), effective thinking (pola berfikir yang efektif), editing (penyuntingan karangan). Brainstorming dan lain lain. $^{24}$

\section{Konsep Diri ( Self Concept ) dan Faktor-Faktor yang Memengaruhi}

Dalam bukunya communicate, Rudolph F. Verderber mendifinisikan konsep diri sebagai "A collection of perception of every aspect of your being: your appearance, physical and mental capabilities, vocational otencial, size, streghth and so fort" (1984:25). Pendapat yang hampir sama tentang konsep diri oleh William D. Brooks dalam bukunya "Speech Communication”. Dikatakan, "Selfconcep then, can be defined as those physical, sosial, and psycological pereptions of ourselves that we hawe derived from experiences and our interaction with others". ${ }^{25}$ Berdasarkan kedua pendapat tersebut diatas dapat disimpulkan bahwa konsep diri adalah "Semua persepsi kita terhadap aspek diri yang meliputi aspek fisik, aspek sosial, dan aspek psikologis, yang didasarkan pada pengalaman dan interksi kita dengan orang lain."26

Kosep diri terbentuk dalam waktu yang relatif lama, dan pembentukan ini tidak bisa diartikan bahwa reaksi yang tidak biasa dari seseorang dapat mengubah konsep diri. Namun, apabila tipe reaksi seperti ini sangat penting terjadi, atau jika reaksi ini muncul karena orang lain yang memiliki arti yaitu orang-orang yang kita nilai, umpanya orangtua, teman dan lain lain.

Sebenarnya konsep diri terbentuk oleh seberapa sering seseorang beriteraksi dengan lingkungannya, Misalnya seorang guru yang mengatakan secara terus

\footnotetext{
${ }^{24}$ Yahya Khan, Pendidikan Karakter Berbasis Potensi Diri, (Yogyakarta: Pelangi Publishing, 2010)., op.cit. h. 3-4.

${ }^{25}$ Alex sobur, Psikologi Umum Dalam Lintas Sejarah, (Bandung, Penerbit Pustaka Setia), h. 507.

${ }^{26}$ Ibid.
} 
ISTIGHNA, Vol. 1, No 2, Juli 2018 P-ISSN 1979-2824

Homepage: http://e-journal.stit-islamic-village.ac.id/index.php/istighna

Amita Diananda

Urgensi Pendidikan Karakter Dalam Pembentukan Konsep Diri Anak

menerus pada seorang muridnya bahwa ia kurang mampu, lama kelamaan anak akan mempunyai konsep seperti itu.

Konsep diri pada dasarnya tersusun atas berbagai tahapan. Yang paling dasar adalah Pertama, konsep diri primer, yaitu konsep yang terbentuk atas dasar penglamannya terhadap lingkungannya terdekat, yaitu lingkungan ruamahnya sendiri. Pengalaman-pengalaman berbeda yang ia terima melalui anggota rumah, dari orangtua, nenek, paman, ataupun saudara-saudaranya. Kedua, konsep diri sekunder, yaitu banyak ditentukan oleh konsep diri primernya. Jadi, apabila konsep diri primer yang dilimiliki seseorang adalah tergolong orang yang pendiam, penurut, tidak nakal, atau tidak suka membuat keributan, ia akan cenderung pula memilih teman-teman bermain yang sesuai dengan konsep diri yang sudah dimilikinya, dan teman-taman sebayanya itulah yang nantinya menunjang terbentuknya konsep diri sekunder. ${ }^{27}$

Konsep diri anak yang bersifat primer dapat dikaitkan dengan ragam pola asuh orangtua terhadap anaknya dan kecenderungan-kecenderungannya yang bisa membentuk konsep diri anak.

Pada tabel 1 berisi mengenai ragam pola asuh dan akibat kecenderungankecenderunganya. ${ }^{28}$

\section{TABEL 1}

PERBANDINGAN

\section{Ragam Pola Asuh Yang Umum}

Saat Orang Tua Mengunakan Pola Asuh Ini ...

Anak Cenderung ...

\section{Otoritatif}

- Menyediakan lingkunagn rumah yang penuh kasih dan suportif

- Menerapkan ekspektasi dan standar yang tinggi dalam berperilaku

- Menjelaskan mengapa beberapa perilaku dapat diterima sedangkan perilkau lainnya tidak

- Menegakkan aturan-aturan keluarga secara konsisten

- Melibatkan anak dalam proses pengambilan

- Gembira

- Percaya diri

- Memiliki rasa ingin tahu yang sehat

- Tidak manja dan berwatak mandiri

- Kontrol diri yang baik

- Mudah disukai; memiliki keterampilan sosial yang efektif

\footnotetext{
${ }^{27}$ Ibid., h. 510-511.

${ }^{28}$ Jeanne Ellis Ormrod, Psikologi Pendidikan Membantu Siswa Tumbuh dan Berkembang, (Jakarta: Penerbit Erlangga, 2008), Ed. 6.Jilid 1. H. 95.
} 
ISTIGHNA, Vol. 1, No 2, Juli 2018 P-ISSN 1979-2824

Homepage: http://e-journal.stit-islamic-village.ac.id/index.php/istighna

Amita Diananda

Urgensi Pendidikan Karakter Dalam Pembentukan Konsep Diri Anak

\begin{tabular}{|c|c|}
\hline $\begin{array}{l}\text { keputusan dalam keluarga } \\
\text { - Secara bertahap melonggarkan batasan-batasan } \\
\text { saat anak semakin bertanggung jawab dan } \\
\text { mandiri }\end{array}$ & $\begin{array}{l}\text { - Menghargai kebutuhan- } \\
\text { kebutuhan orang lain } \\
\text { - Termotivasi dan berprestasi di } \\
\text { sekolah }\end{array}$ \\
\hline $\begin{array}{l}\text { Otoritarian } \\
\text { - Lebih jarang menampilkan kehangatan } \\
\text { emosional dibandingkan keluarga otoritatif } \\
\text { - Menerapkan ekspektasi dan standar yang tinggi } \\
\text { dalam berperilaku } \\
\text { - Menerapkan aturan-aturan berperilkau tanpa } \\
\text { mempertimbangkan kebutuhan anak } \\
\text { - Mengharapkan anak mematuhi peraturan tanpa } \\
\text { pertanyaan } \\
\text { - Hanya sedikit ruang bagi dialog timbal balik } \\
\text { antara orang tua dan anak }\end{array}$ & $\begin{array}{l}\text { - } \text { Tidak bahagia } \\
\text { - } \text { Cemas } \\
\text { - Memiliki kepercayaan diri yang } \\
\text { - Kendah } \\
\text { - } \text { Kurang inisiatif } \\
\text { - Kurang memiliki keterampilan } \\
\text { - } \text { Sosial dan perilaku prososial } \\
\text { Memiliki gaya komunikasi } \\
\text { yang koersif dalam } \\
\text { berhubungan dengan orang lain } \\
\text { - Pembangkang }\end{array}$ \\
\hline $\begin{array}{l}\text { Permisif } \\
\text { - Menyediakan lingkungan rumah yang penuh } \\
\text { kasih dan suportif } \\
\text { - Menerapkan sedikit ekspektasi atau standar } \\
\text { berperilaku bagi anak } \\
\text { - Jarang memberi hukuman terhadap perilaku } \\
\text { yang tidak tepat } \\
\text { - Membiarkan anak mengambil keputusan secara } \\
\text { mandiri }\end{array}$ & $\begin{array}{l}\text { - Egois } \\
\text { - Tidak termotivasi } \\
\text { - Bergantung pada orang lain } \\
\text { - Menuntut perhatian orang lain } \\
\text { - Tidak patuh } \\
\text { - Impulsif }\end{array}$ \\
\hline $\begin{array}{l}\text { Acuh tak acuh } \\
\text { - Hanya menyediakan sedikit dukungan } \\
\text { emosional terhadap anak (terkadang tidak sama } \\
\text { sekali) } \\
\text { - Menerapkan sedikit ekspektasi atau standar } \\
\text { berperilaku bagi anak } \\
\text { - Menunjukkan sedikit minat dalam kehidupan } \\
\text { anak } \\
\text { - Orang tua tampaknya lebih sibuk mengurus } \\
\text { masalah-masalahnya sendiri }\end{array}$ & $\begin{array}{l}\text { - } \text { Tidak patuh } \\
\text { - Banyak menuntut } \\
\text { - Kontrol diri yang rendah } \\
\text { - Kesulitan mengelola perasaan } \\
\text { frustasi } \\
\text { - Kurang memiliki sasaran- } \\
\text { sasaran jangka panjang }\end{array}$ \\
\hline \multicolumn{2}{|c|}{$\begin{array}{l}\text { Sumber;Baumrind,1971,1999;W.ACollir,Macoppy,Steinbreg,Helherington\&Bornstein } \\
\text { 2000,Decovic\&Janssen1992;Gonzales\&Wolters,2005;lambon, } \\
\text { Mount,Steinbreg\&Dornbsch } \\
\text { 1991;macoppy\&Marten,1983;L.S Miller1995,Paris Marrisson\&Miller,2006 }\end{array}$} \\
\hline
\end{tabular}


ISTIGHNA, Vol. 1, No 2, Juli 2018 P-ISSN 1979-2824

Homepage: http://e-journal.stit-islamic-village.ac.id/index.php/istighna

Amita Diananda Urgensi Pendidikan Karakter Dalam Pembentukan Konsep Diri Anak

Harga Diri dan Konsep Diri merupakan sikap yang hampir sama dan saling berkaitan. Harga Diri (Self- Esteem) adalah dimensi evaluatif global dari diri. Harga diri juga diacu sebagai nilai diri atau citra diri. Misalnya, seoranga anak dapat merasa bahwa ia tidak sekedar seorang manusia, tetapi juga manusia yang baik. Tentu saja tidak semua anak memiliki suatu citra yang seluruhnya positif. Sedangkan Konsep Diri ( self-concept) mengacu pada evaluasi bidang spesifik dari diri sendiri. Anak-anak dapat membuat evaluasi diri dalam bidang kehidupan mereka, akademik, atletik, penampilan, dan lain lain. Secara ringkas, harga diri mengacu pada evaluasi diri yang bersifat global sedangkan konsep diri mengacu kepada evaluasi bidang yang lebih spesifik. ${ }^{29}$

Dalam segala aktifitas anak memunculkan adanya interaksi dengan orang lain. Dari interaksi yang muncul tersebut, terdapat usaha untuk pengaruh memengaruhi antara anak dan orang lain tersebut. Dalam situasi ini, konsep diri berkembang dalam proses saling memengaruhi. Masa kanak-kanak yang dini adalah periode kritis dalam perkembangan konsep diri. Anak mempelajari katakata, seperti cantik, tampan, baik, buruk, bodoh, pintar dan lain lain. Sedangkan pada anak remaja, ia mengalami begitu banyak perubahan dalam dirinya. Sikap atau tingkah lakunya yang diampilkannya juga akan mengalami perubahan, dan sebagai akibatnya, sikap orang lain terhadap dirinya juga akan berubah ubah, menyesuaikan dengan perubahan yang terampil dalam dirinya.

Sebab itu, dapat dimengerti bahwa konsep diri pada seorang remaja cenderung untuk tidak konsisten, dan hal ini karena sikap orang lain yang dipersepsikan oleh si remaja juga berubah. Akan tetapi, melalui cara ini, remaja mengalami perkembangan konsep diri, sampai akhirnya ia memiliki konsep diri yang konsisten.

Teman sebaya juga memengaruhi konsep diri remaja karena teman sebaya mempunyai hubungan emosional lebih dekat dan banyak menyediakan sumber informasi dan perbandingan tentang dunia di luar keluarga. Kerap juga terjadi dalam masa perkembangannya mengalami konflik antara yang diharapkannya dan

\footnotetext{
${ }^{29}$ John W. Santrock, Life Span Development, (Jakarta, Penerbit Erlangga, 2002), Ed. Kelima. Jilid.1. h.356.
} 
ISTIGHNA, Vol. 1, No 2, Juli 2018 P-ISSN 1979-2824

Homepage: http://e-journal.stit-islamic-village.ac.id/index.php/istighna

Amita Diananda Urgensi Pendidikan Karakter Dalam Pembentukan Konsep Diri Anak

apa nyatanya ia amati melalui sikap orang lain terhadap dirinya. Dengan situasi seperti itu, adalah proses dalam mengembangkan konsep dirinya.

Berkaitan dengan konsep diri, dalam bukunya Fundamentals of Human Communication, Robert G. King (Yulianita, 1990) memberikan 6 (enam) macam gambaran tentang mengembangkan konsep dirinya yaitu: ${ }^{30}$

1. Me as I am ( Saya sebagai saya)

Merupakan saya yang realitas, nyata yang sebenarnya. Untuk ini hanya Tuhan yang tahu tentang saya yang sebenarnya, karena kita tidak bisa mengetahui diri kita secara benar, lengkap, tepat dan objektif tentang diri kita.

2. Me as I Think I am ( Saya sebagaimana yang saya pikir tentang saya)

Pandangan saya tentang diri saya. Melihat berbagai gambaran mengenai berbagai aspek tentang diri saya, sebagai sebuah fisik tersusun dalam suatu struktur, pendapat itu bukaan fakta.

3. Me as Others Thunk I am ( Saya sebagaimana orang lain berfikir tentang saya).

Saya berpikir sebagaimana pandangan oranglain terhadap saya. Karena itu, bukan saya yang haqiqi, tetapi saya menurut pandangan orang lain.

4. Me as I Think Others Think I Am ( saya sebagaimana yang saya pikir tentang orang lain memandang saya).

Saya mempunyai kean bahwa pandangan orang lain terhadap saya adalah sebagaimana apa yang ada dalam pikiran saya.

5. Me as I Think I Ought to be ( Saya seperti yang saya yang seharusnya)

Seharusnya saya menjadi apa. Ini adalah gambaran ego yang ideal tentang apa yang seharusnya.

6. Me as Think I measure up what I Think I Ought to be ( Saya sebagaimana yang saya pikir menurut saya tentang apa yang menjadi seharusnya saya).

${ }^{30}$ Alex sobur, Psikologi Umum Dalam Lintas Sejarah, (Bandung, Penerbit Pustaka Setia), op.c it., h.522. 
ISTIGHNA, Vol. 1, No 2, Juli 2018 P-ISSN 1979-2824

Homepage: http://e-journal.stit-islamic-village.ac.id/index.php/istighna

Amita Diananda Urgensi Pendidikan Karakter Dalam Pembentukan Konsep Diri Anak

Disini, saya berpikir bahwa saya harus menjadi sesuatu. Misalnya, menurut saya, seharusnya saya menjadi pendidikan, direktur jenderal, rektor, dekan, ketua jurusan, dosen dan sebagainya.

Jika dicermati, sebenarnya ada dua aspek yang menjadi orientasi pendidikan karakter. ${ }^{31}$ Pertama, membimbing hati nurani peserta didik agar berkembang lebih positif secara bertahap dan berkesinambungan. Hasil yang diharapkan, hati nurani peserta didik akan mengalami perubahan dari semula egosentris menjadi altruis. Kedua, memupuk, mengembangkan, menanamkan nilai-nilai dan sifatsifat positif ke dalam pribadi peserta didik.

Pendidikan karakter memiliki misi untuk menghancurkan mental block . Mental block adalah cara berpikir dan perasan yang terhalangi oleh ilusi-ilusi yang sebenarnya hanya membuat seseorang terhambat untuk melangkah menuju kesuksesan.

\section{E. Kesimpulan}

1. Pendidikan karakter ditamankan sejak dini kepada anak oleh keluarga, sekolah dan masyarakat

2. Pendidikan karakter pada dasarnya adalah pengembangan nilai-nilai yang berasal dari pandangan hidup atau idiologi Bangsa Indonesia, agama, budaya dan nilai-nilai yang terumuskan dalam tujuan pendidikan nasional

3. Konsep Diri anak melalui proses yang cukup lama dan terbentuk berdasarkan persepsi seseorang tentang sikap orang lain terhadap dirinya.

\section{DAFTAR PUSTAKA}

Amrullah Syahrbini, Model Pendidikan Karakter Dalam Keluarga, (Jakarta: PT Elex Media Komputindo, 2014)

Alex sobur, Psikologi Umum Dalam Lintas Sejarah, (Bandung, Penerbit Pustaka Setia)

\footnotetext{
${ }^{31}$ Zubaidi, Desain Pendidikan Karakter Konsepsi dan Aplikasinya dalam Lembaga Pendidikan, (Jakarta: Penerbit Kencana, 2011), op.cit.,h. 184.
} 
ISTIGHNA, Vol. 1, No 2, Juli 2018 P-ISSN 1979-2824

Homepage: http://e-journal.stit-islamic-village.ac.id/index.php/istighna

Amita Diananda Urgensi Pendidikan Karakter Dalam Pembentukan Konsep Diri Anak

Dimyati, Peran Guru sebagai Model dalam Pembelajaran Karakter dan Kebajikan Moral melalui Pendidikan Jasmani, (Yogyakarta: UNY, 2010, Th.XXIX)

Kak Hendri, Pendidikan Karakter Berbasis Dongeng,(Bandung, Simbiosa Rekatama Media)

Jalaluddin, Psikologi Agama, (Jakarta: PT Raja Grafindo Persada, 2004)

Jeanne Ellis Ormrod, Psikologi Pendidikan Membantu Siswa Tumbuh dan Berkembang, (Jakarta: Penerbit Erlangga, 2008)

John W. Santrock, Life Span Development, (Jakarta, Penerbit Erlangga, 2002)

Yahya Khan, Pendidikan Karakter Berbasis Potensi Diri, (Yogyakarta: Pelangi Publishing, 2010

Zubaidi, Desain Pendidikan Karakter Konsepsi dan Aplikasinya dalam Lembaga Pendidikan, (Jakarta: Penerbit Kencana, 2011)

http://nopawilyanita.blogspot.com/2014/02/pendidikan-anak-usia-dini-pauddan.html https://id.wikipedia.org/wiki/Budaya https://www.kompasiana.com/m.trimanto/5893efcbf692733a1bf67257/pendidikan

- berbasis-budaya

http://www.rakyatpos.com/membangun-karakter-peduli-lingkungan-di-sekolahupaya- penyelematan-lingkungan-hidup.html/

https://kbbi.web.id/karakter Sumber: Kamus Bahasa Indonesia edisi elektronik(2008) 